\title{
Use of Modelling Approach in evaluation of Fractured Shale Aquifers for irrigation purpose; a case study of Oju, Lower Benue Trough Nigeria
}

\section{O. Eyankware*a, C, Ogwah ${ }^{\mathrm{a}}$}

aDepartment of Geology, Faculty of Sciences, Ebonyi State University, Abakaliki, Ebonyi State. Nigeria.

*Corresponding Author email: geomoses203@gmail.com. Phone number: +2348065269907

\section{DOI: $10.2478 / p j g-2019-0001$}

\begin{abstract}
:
Groundwater samples were evaluated for irrigation purpose, within selected part of Oju area of Benue State, Nigeria. The study area lies within Asu River Group of the Lower Benue Trough, southern part of Nigeria. Physicochemical parameters were analyzed using APHA, 2012 method. Results from the study showed that $\mathrm{pH}$ falls within slightly basic to acidic, with Ec value ranging from 127 to $760 \mu \mathrm{S} / \mathrm{cm}$, SSP ranges from 1.53 to 43.78 , Sodium Percentage ranges from 1.55 to $77.8 \%$, Kelly Ratio ranges from 0.01 to 0.77 , Magnesium Absorption Ratio ranges from 0.00 to 61.98 and total hardness Total Hardness ranges from 72.00 to 425.5 within the study area. The above listed parameters were below various permissible standard value for irrigation except for MAR at LBT/04, Na \% at LBT/09, 13 and 14, SAR at 01 and 04 and TH at LBT/04 that were slightly above various permissible standard values. From Gibbs plot it was observed that rock dominance is the major factor that influences groundwater except for few sampling point were precipitation dominance was observed to have influence on groundwater within the study area.
\end{abstract}

Keywords: Sodium Percentage, Kelly Ratio, Exchange, Lower Benue Trough and Shallow

\section{Introduction:}

Groundwater can be regarded as of the one most important natural resource, large percentage of it exists within the study area at various depth(s) and exist in fractures [1]. Other researchers further stated that depth to water table and borehole yield also varies [2]. Exploitation of groundwater within the study area is largely through hand-dug wells and motorized borehole, area around the Ukwokwu Hills tends to be more fractured and have high groundwater potentials compared to other parts of the study area, due to tectonic activities that occurred within Ukwokwu Hills, Groundwater resources within Asu River Group is limited, and even the limited water resource is still prone to pollution from anthropogenic activities and also pose as treat its quality for domestic, industrial and agricultural [2-5]. Most human waste are channeled into surface water, while the other infiltrate into groundwater thereby altering the quality for various use. Generally, groundwater is considered less prone to pollution compare to surface water especially, in area where there is less anthropogenic activities that will alter its chemistry. Groundwater is considered as the major source of water available all year round as most of the surface water dry up during the dry season [6]. Demand for groundwater has been on high side for domestic, agricultural and industrial use globally [7-9]. Its availability for irrigation has contributed to increase in crop productivity in country like Bangladesh [7]. But the reverse is the case in Nigeria as most research on groundwater are channeled towards its evaluation for drinking purpose. In other studies, they had evaluated groundwater quality for domestic use within the Lower Benue Trough $[6,10]$. Hence the need for evaluation of groundwater for irrigation. As for Irrigation water emphasis is placed on the physicochemical attribute of water and on rare situation are other factors considered important [4].

\subsection{Location and Accessibility}

The study area lies within in latitude $6050^{\prime} \mathrm{N}-6055^{\prime} \mathrm{N}$ and longitude $8022^{\prime} \mathrm{E}-8027^{\prime} \mathrm{E}$ Oju, local government area of Benue Sate [10]. It is accessible by Otukpo/Oju road, with some other minor road Nkache, Ameke and others as shown in Figure 1.

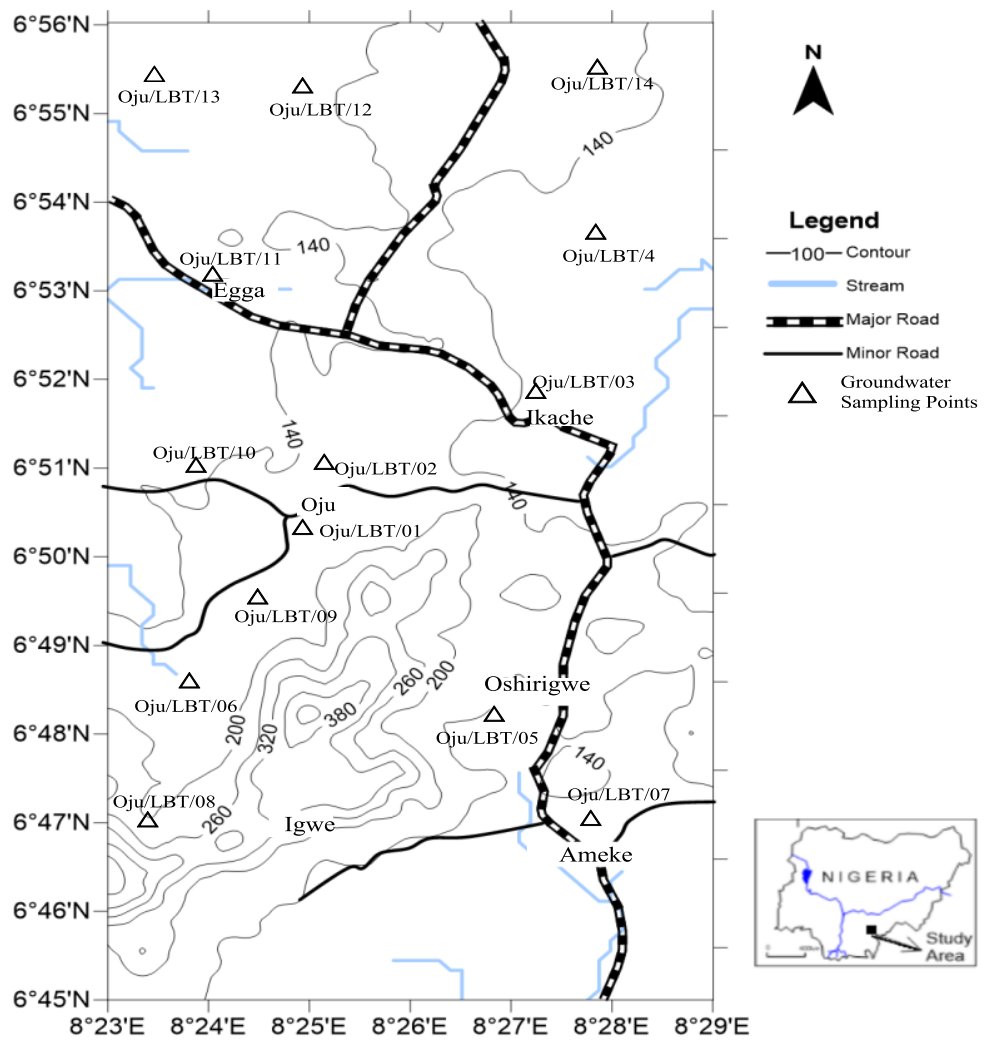

Figure 1: Topography Showing Water Sampling Map of the Study Area.

\subsection{Vegetation and Climate}

A researcher stated that the climate of Nigeria is classified into two major seasons namely: dry and rainy season [11]. The dry season prevails from November to March, but between December and early month of February and the Sahara anticyclone from the northern hemisphere causes dry and dust laden air mass blowing from across the desert through parts of the northern Nigeria. The area is characterized by relatively warm temperature days of 270 
$\mathrm{C}$ to $320 \mathrm{C}$ and moderately cool nights of $170 \mathrm{C}$ to $280 \mathrm{C}$. The rainy season start from April to October with an august break or little period of no rain. The rains occur as violet downpours accomplished by thunderstorms, heavily flooding, soil and gully erosion and fast groundwater infiltration within the study area and also experience high relative humidity of about $65 \%$ to $80 \%$ with it peak of rain season when there is medium to low sunshine hours and low evaporation. Drainage and topography are the two main factors known to control the vegetation of any locality and that of the study area is not excluded. Sparse vegetation may be found on the Plateau while luxuriant vegetation occurs in the plains. The highland areas within the Ukwokwu Hills have grasses and few shrubs, while the lowland areas and valleys consist of few grasses.

\subsection{Hydrogeology of the study area}

Hydrochemistry of groundwater is controlled by the rocks and sediments through which these waters flow through [12,13]. Generally, groundwater movement and storage within the area of study is influenced by three main factor; thickness, lithology and structure of rock formation (predominantly shales of the Asu River Group). Shale is an aquiclude and does not permit reasonable quantity of water, except when it exist when its fractured shale that is when it can serve as water bearing unit. There are, however, intercalations of clays and sand clays which have led to artesian conditions in the study area. In the same vein, groundwater in the areas generally exists in fractured zones within the Asu River Group, sandstone and limestone layers or members, weathered zones, and bedrock interfaces with shale group [14]. The Asu River facies are poor in groundwater potentials.

\subsection{Regional Tectonic Setting}

The Benue right has been referred to a Benue valley, Benue depression, Benue Trough and Benue aulacogen [15-17]. It is known to be an intra continental rift basin which is a part of the Gulf of Guinea, South Atlantic, Benue triple junction with its centre occupied by the Niger Delta. Geographically it is stbdivided into the Upper, Middle and Lower parts. The basin is filled mainly by Pre-Santonian (late Aptian to Coniacian) sedimentary rocks which are believed to have undergone regional burial metamorphism at the anchizonal to lower greenschist grade [18,19]. In a studies and other researcher/ scholar has carried out research on the Benue Trough sedimentary fill and its mainly focused on sedimentary environments and relative age-dating [20,21].

\subsection{Geology of the study area}

The Lower Benue Trough (LBT) is sub-divided into the Asu River Group (ARG), Eze Aku Formation and the Awgu Formation based on time and age as shown in Table. 1. Asu River Group: This stratigraphic unit was first named after the Shell D' Arcy area geologist and it was referred to formation the oldest sedimentary unit in the Western Cross River plain [22]. This group entails the initial cretaceous trangessive sediment in the sub-basin [23]. It was generally described as the Lower shale and Cross River - Benue Shale, Asu River Series and Asu River Formation [24-25]. The Asu River Group uplift displays the most serve deformation in a relatively narrow slip $(20 \mathrm{~km})$ wide running NE-SW for over $200 \mathrm{~km}$. The overall structure sediment as the core. Beds of the Albian Asu River Group facies went through two deformational (folding) phase- a less intense one in the Cenomanian and a more intense phase in Santonian $[26,27]$. This account for the presence of on unconformity within the sedimentary succession of the Lower Benue Trough the sediment between of the Asu River Group facies and the Eze Aku Group facies. The Asu River Group comprises of olive brown or bluish grey shale and sandy shale, fine-grained micaceous sandstone and micaceous mudstone with thin limestone around the Abakaliki area [20]. Nwajide 22 stated that folding episode affected mainly the sediment of the Asu River Group around the Ukwokwu Hill (Workum Hills). He further stated that the folding affected the shale and that the Ukwokwu Hills display specific well-developed cleavage related to low grade metamorphosed resulting indurated slates. The folds form sets were parallel axis resulting mainly from a simple shortening by flexure due to horizontal compression. Both flexural and flattening resulted from the same compressive process but with a combined effect of dragging due to concomitant sharing.

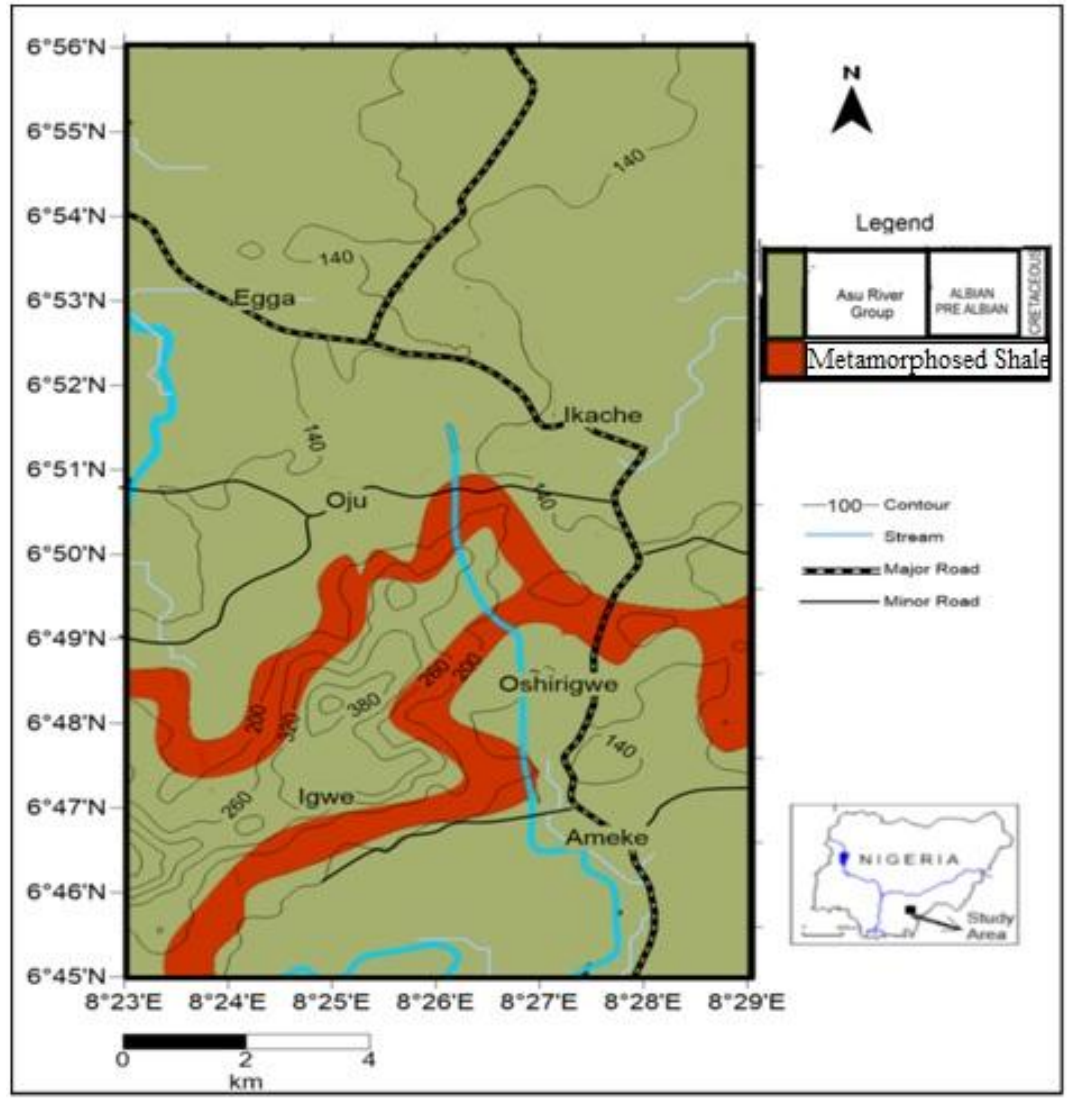

Figure 2: Geology map of the study area.

Table 1: Lithostratigraphic of Lower Benue Trough for the early Cretaceous-Tertiary period in southeastern Nigeria Nwajide [28]. 


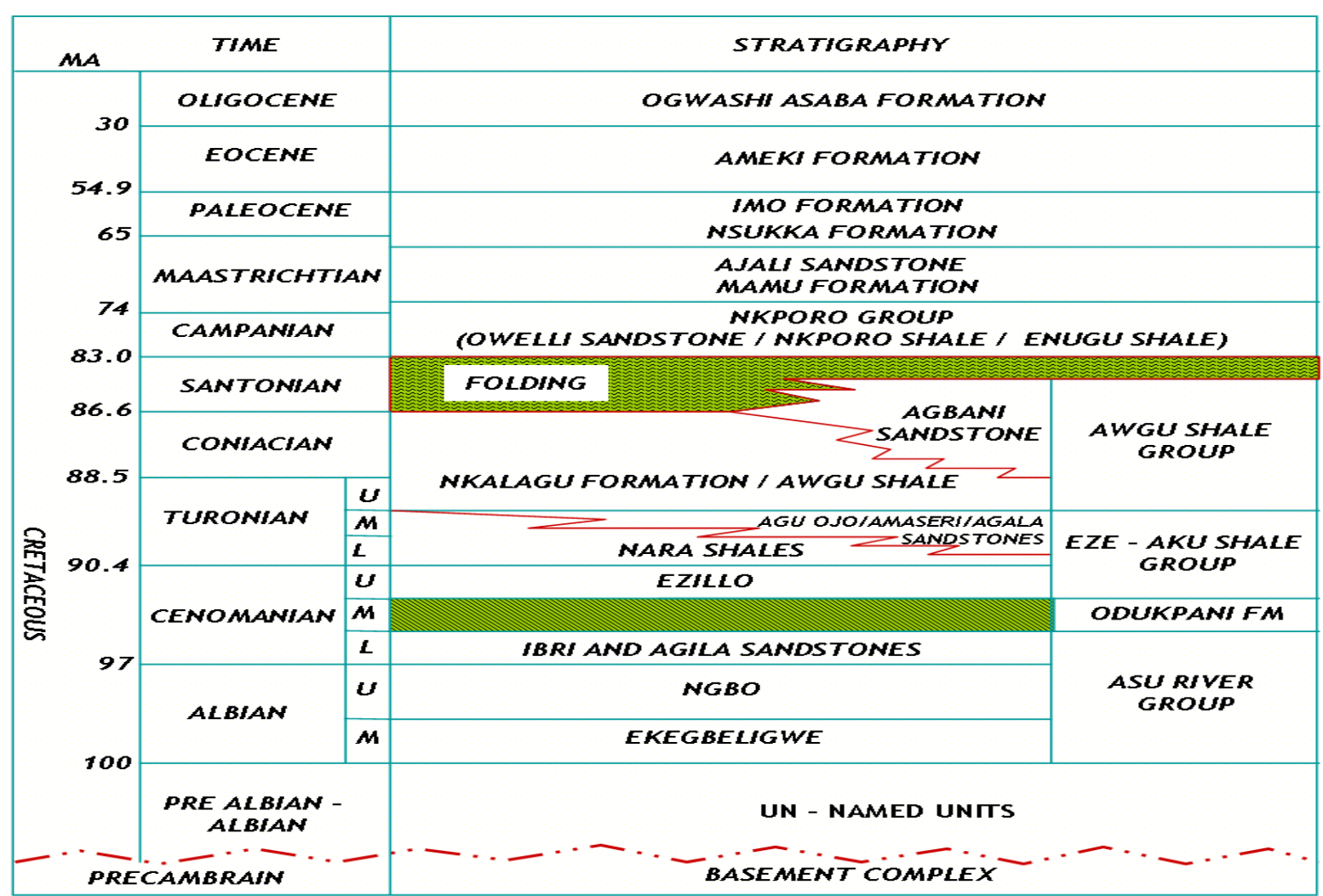

Sampling and Laboratory Analysis

\subsection{Laboratory Method}

Systematic groundwater approach was used in groundwater sampling and various physicochemical parameters were analyzed following see Table 2 [29]. And there result presented in Table 3. Fourteen groundwater samples were collected at various site in 0ju, Benue state Nigeria to get the baseline information on suitability of groundwater for irrigation see Figure 1 and 2.

Table 2: Method used to analyze physicochemical parameters.

\begin{tabular}{|c|c|c|c|}
\hline S/No & Parameters & Unit & Analytical Method \\
\hline 1 & $\mathrm{pH}$ & & $\begin{array}{l}\text { pH meter Hach sensION + PH1 portable pH meter and Hach } \\
\text { sensION + } 5050 \text { T Portable Combination pH Electrode }\end{array}$ \\
\hline 2 & Electrical Conductivity (EC) & $\mu \mathrm{S} / \mathrm{cm}$ & HACH Conductivity \\
\hline 3 & Total dissolved solids (TDS) & $\mathrm{mg} / \mathrm{L}$ & TDS meters (model HQ14D53000000, USA). \\
\hline 4 & Magnesium $\left(\mathrm{Mg}^{2+}\right)$ & $\mathrm{meq} / \mathrm{L}$ & EDTA titrimetric method \\
\hline 5 & Calcium $\left(\mathrm{Ca}^{2+}\right)$ & $\mathrm{meq} / \mathrm{L}$ & Titrimetric method \\
\hline 6 & Chloride $(\mathrm{Cl})$ & $\mathrm{meq} / \mathrm{L}$ & Titrimetric method \\
\hline 7 & Nitrate $\left(\mathrm{NO}_{3}\right)$ & $\mathrm{meq} / \mathrm{L}$ & Ion-selective electrode (Orion 4 star) \\
\hline 8 & Sulphate $\left(\mathrm{SO}_{4}^{2}\right)$ & $\mathrm{meq} / \mathrm{L}$ & Turbidimetric method using a UV-Vis spectrometer \\
\hline 9 & Potassium $\left(\mathrm{K}^{+}\right)$ & $\mathrm{meq} / \mathrm{L}$ & Jenway clinical flame photometer (PFP7 model) \\
\hline 10 & Sodium $\left(\mathrm{Na}^{+}\right)$ & $\mathrm{meq} / \mathrm{L}$ & Ienway clinical flame photometer (PFP7 model) \\
\hline 11 & Bicarbonate $\left(\mathrm{HCO}_{3}\right)$ & $\mathrm{meq} / \mathrm{L}$ & Titrimetric method \\
\hline
\end{tabular}

To determine the accuracy of geochemical analysis ionic balance, was employed and the value obtain was within $(1: 1 \pm 0.01 \%)$ as plotted using Surfer. 10 software package. The suitability of groundwater for irrigation was evaluated by comparing the water samples with various water quality standards for irrigation and calculated using Eqn 3 to 8. All irrigation parameters were calculated for in (meq/L).

\subsection{Analytical check / ionic balancing}

To confirm the correctness of analyzed chemical results, relationship between the anions and the cations in the analyzed samples as expressed in meq/L. The equations are represented as [30-32];

$\%$ Parameters $=\frac{\text { Individual parameter }}{\text { Total parameter }} \times 100$

Eqn. 1 gave a cation-anion ratio of 1:1 \pm 0.01 , which confirms that the geochemical analysis was accurate.

The cation-anion balance was also assessed using electrical neutrality equation which requires that the sum of positive ions must be equal to sum of negative ions in solution expressed in meq/L.

$\%$ difference $\left(\frac{m e q}{L}\right)=\left(\frac{\sum \text { cations }-\sum \text { anions }}{\sum \text { cations }+\sum \text { anions }}\right) \times 100 \%$

\subsection{Irrigation Parameters}

Soluble Sodium Percentage (SSP) Some researchers ascertains the level of sodium in water used for irrigation using SSP [33,34]. 
$S S P=\frac{\left(N a^{+}+K^{+}\right) \times 100}{C a^{2}+M g^{2+}+N a^{+}+K^{+}}$

Magnesium Adsorption Ratio (MAR). A research has assessed the suitability of magnesium ion in natural water using Eqn 4 below [35]

$M A R=\frac{M g^{2+} \times 100}{M g^{2+}+C a^{2+}}$

Sodium Percentage (Na\%) A studied the disadvantage of high sodium concentration in natural water using the equation below [36,37].

$N a \%=\frac{N a^{+} \times 100}{C a^{2+}+M g^{2+}}$

Sodium Adsorption Ratio (SAR). The concentration of sodium in relation to $\mathrm{Na}+, \mathrm{Ca} 2+, \mathrm{Mg} 2+$ is assessed using the equation according to a study to calculate SAR [33]. Thus,

$S A R=\frac{N a^{+}}{\sqrt{\frac{C a^{2+}+M g^{2+}}{2}}}$

Kelly's Ratio (KR) This parameter measures the concentration of $\mathrm{Na}+$ against the concentration of the alkaline earth metals (Ca2+ and Mg2+). The equation was used to calculate KR [38].

$K R=\frac{N a^{+}}{C a^{2+}+M g^{2+}}$

Total Hardness (TH). The softness or hardness of water for irrigation is assessed using the relation [35,39]. Thus,

$T H=\left(\mathrm{Ca}^{2+}+\mathrm{Mg}^{2+}\right) \times 100$

Potential Salinity (PS). A study, proposed the suitability of water for irrigation using potential salinity see eqn. 9 [39].

$\mathrm{Cl}^{-} \sqrt{\mathrm{SO4} 4^{--}}$

[37]; [39]

(9)

\section{Gibb's Plot}

For Cations

$\mathrm{Na}^{+} /\left(\mathrm{Na}^{+}+\mathrm{Ca}^{2+}\right) \mathrm{meq} / \mathrm{L}$

(10a)

$\mathrm{Cl}^{-} /\left(\mathrm{Cl}^{-}+\mathrm{HCO}_{3}^{-}\right) \mathrm{meq} / \mathrm{L}$

[40]

(10b)

Table 3: Result of Physical and Chemical Parameters

\begin{tabular}{|c|c|c|c|c|c|c|c|c|c|c|c|}
\hline $\begin{array}{l}\text { Sample } \\
\text { Code }\end{array}$ & $\begin{array}{l}\mathrm{Ec} \\
(\mu \mathrm{S} / \mathrm{cm})\end{array}$ & $\mathrm{pH}$ & $\begin{array}{l}\text { TDS } \\
\mathrm{mg} / \mathrm{L}\end{array}$ & $\begin{array}{l}\mathrm{Cl}^{-} \\
\text {(meq/L) }\end{array}$ & $\begin{array}{l}\mathrm{Ca}^{2+} \\
(\mathrm{meq} / \mathrm{L})\end{array}$ & $\begin{array}{l}\mathrm{Mg}^{2+} \\
(\mathrm{meq} / \mathrm{L})\end{array}$ & $\begin{array}{l}\mathrm{Na}^{+} \\
(\mathrm{meq} / \mathrm{L})\end{array}$ & $\begin{array}{l}\mathrm{NO}^{3-} \\
(\mathrm{meq} / \mathrm{L})\end{array}$ & $\begin{array}{l}\mathrm{SO}_{4}^{2-} \\
(\mathrm{meq} / \mathrm{L})\end{array}$ & $\begin{array}{l}\mathrm{K}^{+} \\
(\mathrm{meq} / \mathrm{L})\end{array}$ & $\begin{array}{l}\mathrm{HCO}_{3^{-}} \\
(\mathrm{meq} / \mathrm{L})\end{array}$ \\
\hline $\mathrm{LBT} / 01$ & 727 & 6.6 & 473 & 0.00 & 3.41 & 1.64 & 1.18 & 0.03 & 0.00 & 0.03 & 0.08 \\
\hline $\mathrm{LBT} / 02$ & 531 & 6.8 & 167 & 0.02 & 3.20 & 1.07 & 1.66 & 0.04 & 0.00 & 0.05 & 0.10 \\
\hline $\mathrm{LBT} / 03$ & 590 & 6.6 & 294 & 0.00 & 4.50 & 0.00 & 0.07 & 0.02 & 0.21 & 0.04 & 0.14 \\
\hline $\mathrm{LBT} / 04$ & 760 & 6.7 & 372 & 0.00 & 3.44 & 5.61 & 2.01 & 0.04 & 0.02 & 0.09 & 0.03 \\
\hline $\mathrm{LBT} / 05$ & 670 & 7.4 & 355 & 0.00 & 2.92 & 0.00 & 1.13 & 0.03 & 0.04 & 0.03 & 0.29 \\
\hline LBT/06 & 318 & 7.7 & 199 & 0.00 & 2.61 & 1.45 & 0.48 & 0.03 & 0.00 & 0.02 & 0.01 \\
\hline $\mathrm{LBT} / 07$ & 430 & 6.6 & 277 & 0.00 & 2.11 & 0.68 & 0.96 & 0.04 & 0.04 & 0.17 & 0.18 \\
\hline LBT/08 & 404 & 6.8 & 283 & 0.00 & 0.91 & 1.97 & 0.61 & 0.05 & 0.08 & 0.05 & 0.40 \\
\hline LBT/09 & 314 & 6.7 & 225 & 0.00 & 1.89 & 2.21 & 2.33 & 0.03 & 0.02 & 0.04 & 0.13 \\
\hline $\mathrm{LBT} / 10$ & 362 & 6.5 & 199 & 0.00 & 2.93 & 1.89 & 0.45 & 0.04 & 0.00 & 0.07 & 0.22 \\
\hline $\mathrm{LBT} / 11$ & 253 & 6.70 & 95 & 1.00 & 1.34 & 0.10 & 0.99 & 0.08 & 0.05 & 0.02 & 0.39 \\
\hline $\mathrm{LBT} / 12$ & 146 & 6.90 & 74 & 1.00 & 0.56 & 1.04 & 0.75 & 0.05 & 0.11 & 0.06 & 0.35 \\
\hline $\mathrm{LBT} / 13$ & 254 & 7.20 & 101 & 0.42 & 2.17 & 0.00 & 1.69 & 0.02 & 0.10 & 0.08 & 0.22 \\
\hline $\mathrm{LBT} / 14$ & 127 & 6.70 & 92 & 1.00 & 1.46 & 0.00 & 0.88 & 0.05 & 0.23 & 0.03 & 0.09 \\
\hline Minimum & 127 & 6.5 & 74 & 0.00 & 0.56 & 0.00 & 0.07 & 0.02 & 0.00 & 0.02 & 0.01 \\
\hline Maximum & 760 & 7.7 & 473 & 1.00 & 4.5 & 5.61 & 2.33 & 0.08 & 0.23 & 0.17 & 0.4 \\
\hline Average & 423.31 & 6.88 & 234.56 & 0.27 & 2.40 & 1.45 & 1.09 & 0.04 & 0.07 & 0.06 & 0.19 \\
\hline
\end{tabular}

\subsection{Result and discussion}

\subsection{Soluble Sodium Percentage (SSP)}

A study stated that if the value of SSP is $<50$, it implies that the water is considered suitable for irrigation, while value above 50 indicates that the water is unsuitable for irrigation [34]. The values of SSP within the study area range from 1.53 to 43.78 with an average value of 22.61 see Figure 3 and Table 5. The sample locations are considered suitable for irrigation because the SSP values within the study area is $<50$, the standard limit. Table 5 


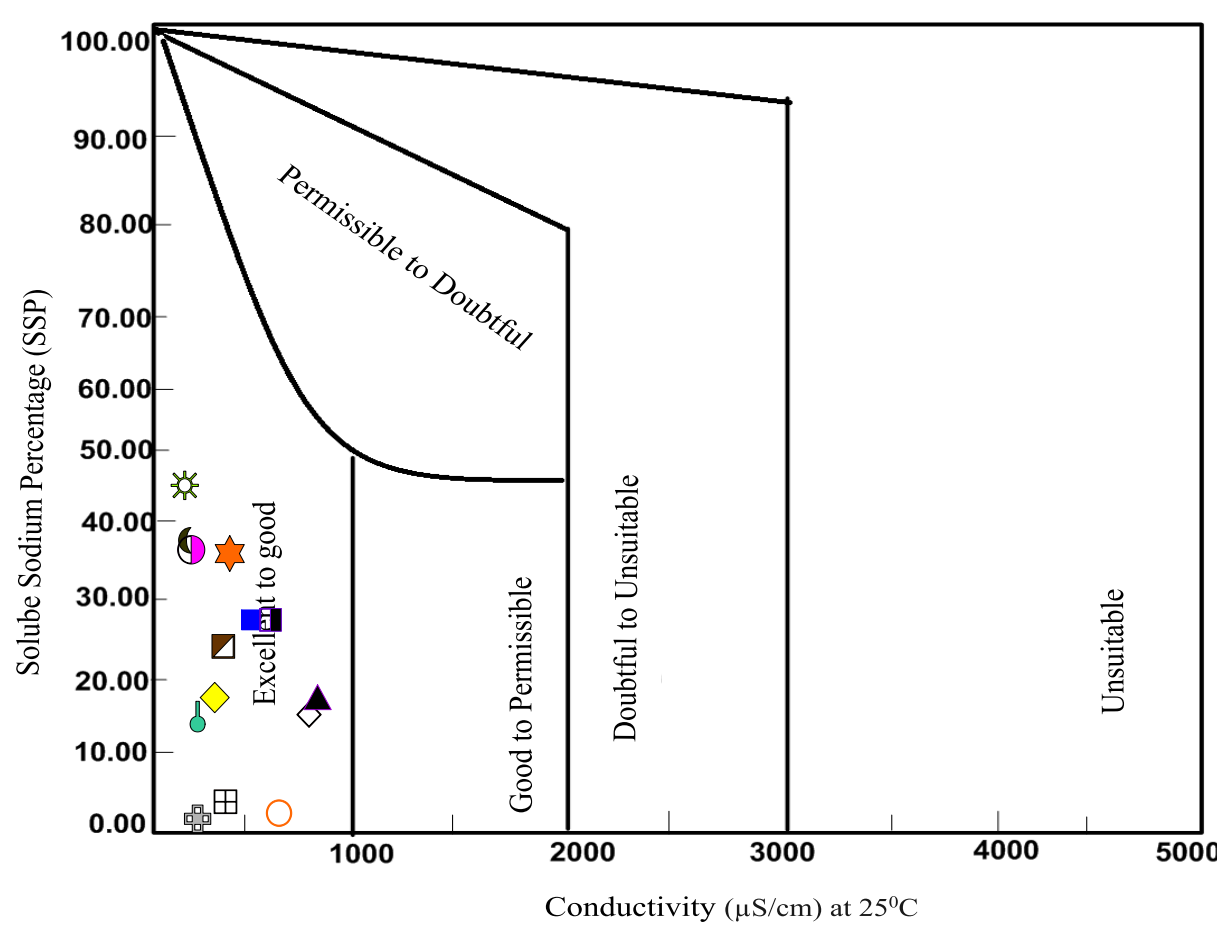

\begin{tabular}{|c|c|}
\hline \multicolumn{2}{|c|}{ Legend } \\
\hline $\mathrm{LBT} / 01$ & \\
\hline LBT/02 & \\
\hline LBT/03 & \\
\hline LBT/04 & \\
\hline LBT/05 & प \\
\hline LBT/06 & II \\
\hline LBT/07 & $\angle$ \\
\hline LBT/08 & \\
\hline LBT/09 & है \\
\hline LBT $/ 10$ & 田 \\
\hline LBT/11 & 䛛 \\
\hline $\mathrm{LBT} / 12$ & ( \\
\hline $\mathrm{LBT} / 13$ & 8 \\
\hline $\mathrm{LBT} / 14$ & $a$ \\
\hline
\end{tabular}

Figure 3: Showing Wilcox Diagram of sampled groundwater within the study Area.

6.1.1 Magnesium adsorption ratio (MAR)

A studies stated that $\mathrm{Ca} 2+$ and $\mathrm{Mg} 2+$ maintain a state of equilibrium in most waters and that high concentration of magnesium in water is believed to have adverse effect on crop yields as the soil becomes more alkaline [41]. Munshower, further stated that value less than 50 is considered to be the acceptable limit for MAR [42]. The value of MAR within the study area ranges from 0.00 to 61.98 with an average of 22.19 see Table 5. From results obtained from MAR, sampled locations are considered fit irrigation except LBT/04 with value of 61.98, hence his LBT/04 is considered not fit for irrigation, see Table 5 . When the concentration of magnesium ions is high it usually alter soil infiltration properties as they are about $50 \%$ bigger than calcium ions and are not very strongly attracted to the clay particles. This could result to more water to be adsorbed between the magnesium ions and clay particles thereby reducing the overall soil infiltration rates.

\subsubsection{Sodium Percentage ( $\mathrm{Na} \%)$}

Sodium percentage is one major model in defining fitness of groundwater for irrigation. It's also an important factor to use in determining sodium hazard [2]. The value of $\mathrm{Na} \%$ within the study area ranges from to 1.15 to $77.80 \%$ with an average value of $36.96 \%$ see Figure 4 and Table 5 . Based on the values of $\mathrm{Na} \%$ from the study area sample location LBT/01 to 14 is considered suitable for irrigation purpose.

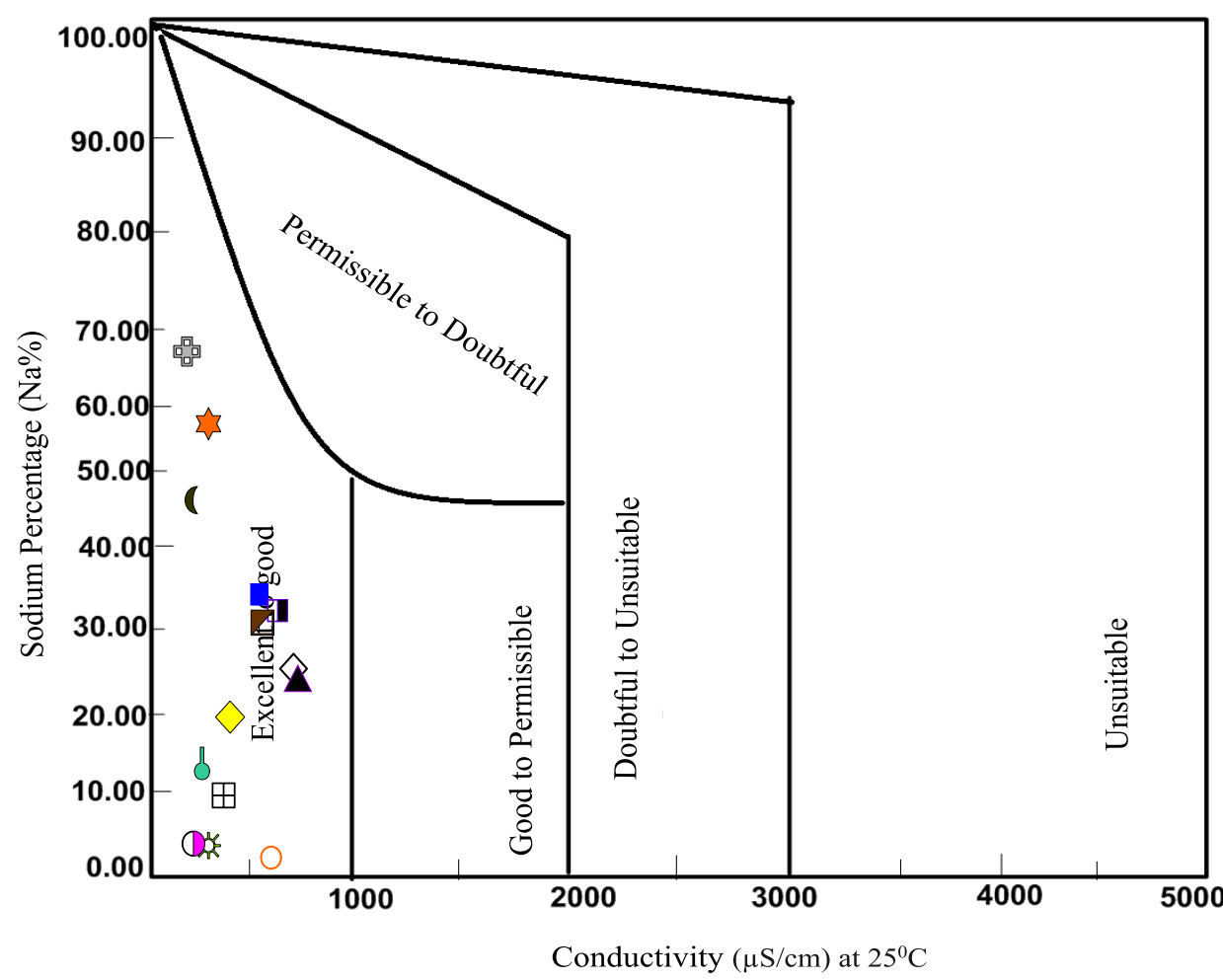

\begin{tabular}{|c|c|}
\hline \multicolumn{2}{|c|}{ Legend } \\
\hline LBT/01 & \\
\hline LBT/02 & \\
\hline LBT/03 & \\
\hline LBT/04 & \\
\hline LBT/05 & \\
\hline LBT/06 & 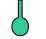 \\
\hline LBT/07 & \\
\hline LBT/08 & \\
\hline LBT/09 & \\
\hline $\mathrm{LBT} / 10$ & t \\
\hline LBT/11 & 回 \\
\hline $\mathrm{LBT} / 12$ & \\
\hline LBT/13 & \\
\hline LBT/14 & \\
\hline
\end{tabular}

Figure 4: Rating of water samples on the basis of electrical conductivity and sodium percent [43].

Some study stated that when the value of SAR $>12$ to 15 , this could lead to serious physical soil problems that make it difficult for plant to absorb water $[42,44]$. One of irrigation parameters that help give detailed information on concentration of $\mathrm{Na}+\mathrm{Ca} 2+$ and $\mathrm{Mg} 2+$ in the water samples is SAR. It also 
another parameter that consider the fact that the adverse effect of sodium is influenced by the occurrence of Ca2+ and Mg2+ ions. The value of SAR within the study area ranges from 0.04 to 1.39 with an average value of 0.70 see Figure $5 \mathrm{a}$ and Table 5. From Figure 5a sample location LBT/12 and 14 falls within the C1 (excellent) category, while LBT/02, 03, 05, 06, 07, 08, 09, 10 and 11 falls within the C2 (good) category and LBT/01 and 04 falls within the C3 (doubtful) category.
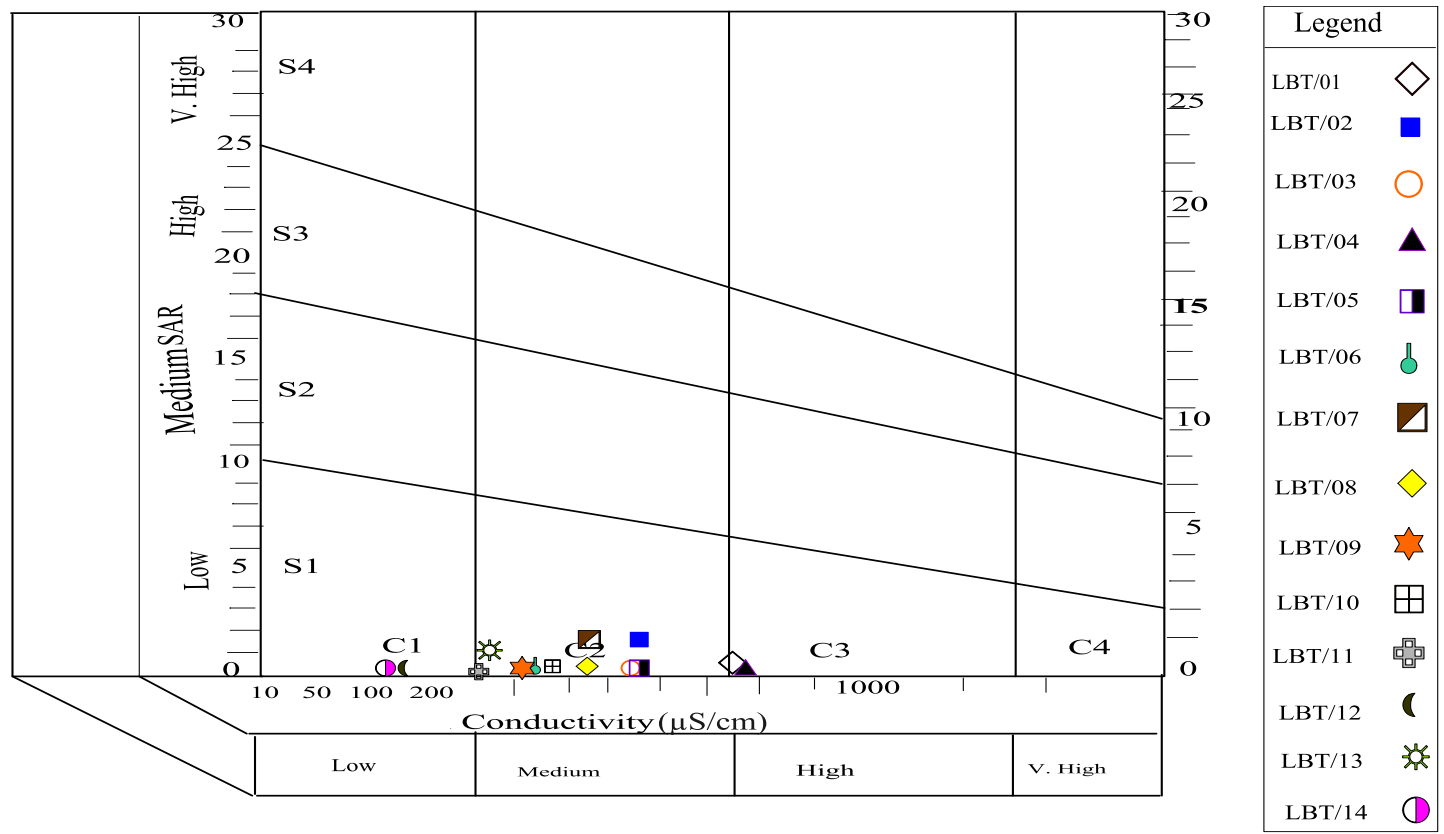

Figure 5a: Classification of water based on [45]

Where C1 = Excellent, C2 = Good, C3 =Doubtful, C4 = Unsuitable, S1 = Excellent, S2 = Good, S3 =Doubtful, S4 = Unsuitable.

A researcher stated that groundwater samples with higher salinity is needed for soil structure [46]. From Figure (5b) one could see the influence of irrigation water on the soil properties (infiltration rate in the present study). The low SAR values (average of 0.70) see Table 5. In a study stated that SAR of irrigation water represents the tendency of Na ions to be adsorbed at ion exchange sites within the soil matrix at the expense of calcium and magnesium this result in the dispersion of soil particles, which could reduce the soil infiltration capacity [47]. However, slight reduction in soil permeability that is attributed to high result from SAR values of irrigation water can be brought to minimal by the high salinity values (EC of groundwater). With similar SAR values, samples with higher salinity are considered useful for the soil structure [46]. The map of SAR versus EC (Figure 5b) shows the influence of irrigation water on the soil properties (infiltration rate in the present study). The low SAR values (average of 0.70 ) and high salinity values (average of $0.41 \mathrm{dS} / \mathrm{m}$ ) results in the water samples falling within slightly to moderate reduction infiltration category. From Figure $5 \mathrm{a}$ and $5 \mathrm{~b}$, it was observed that groundwater does not have any influence on soil infiltration attribute and do not really need an extra effort such as; addition of Ca2+ to improve the soil attribute, but the high salinity values may have side effect on plant growth. A better approach is to grow plants and crops which are high salinity resistant.

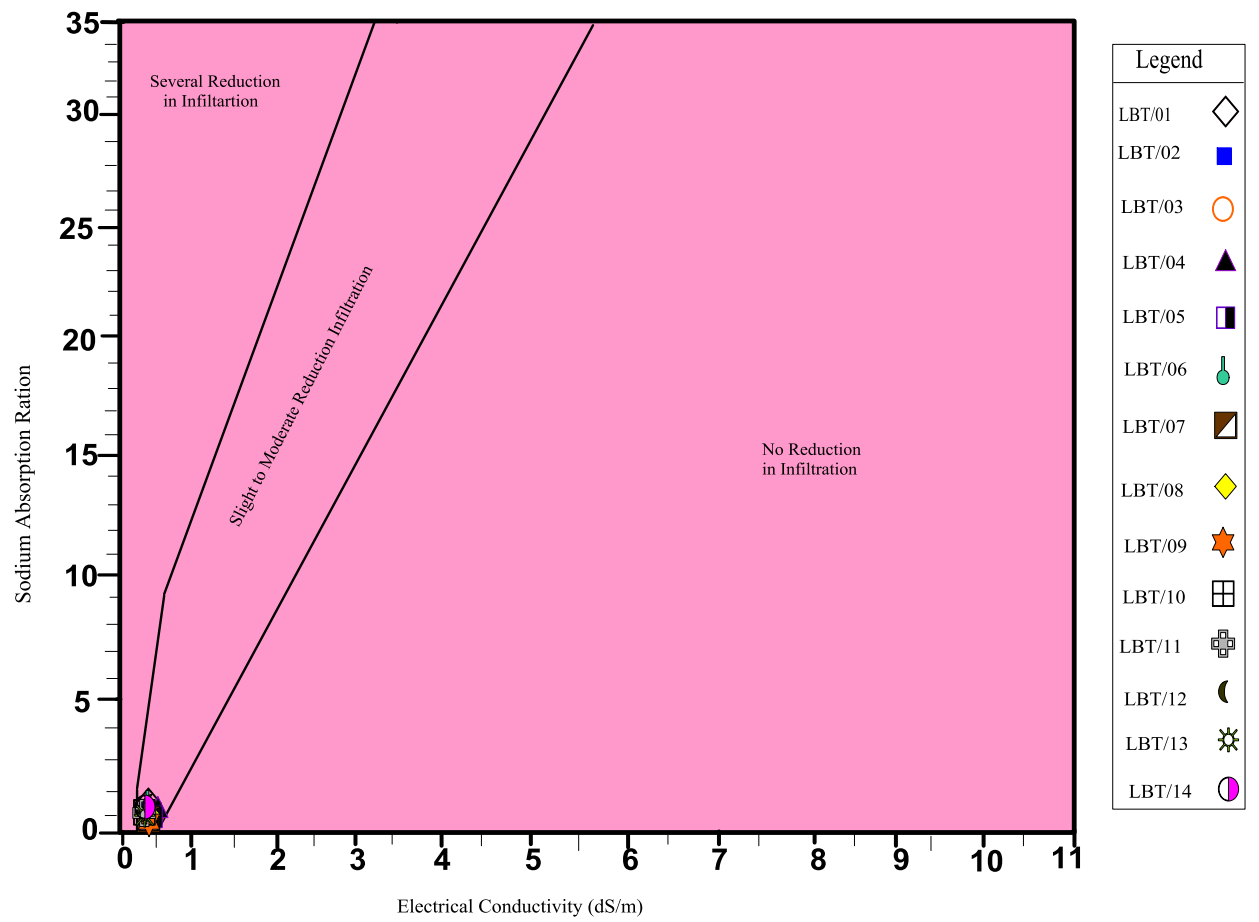

Figure 5b: Plot of SAR against EC that helps to show impact groundwater within the Study Area on Soil Infiltration rate [46].

6.1.4 Kelly Ratio (KR)

Researcher stated that when KR is equal to or below 1 , it implies that the water is considered fit for irrigation use, when the value is above 1 it suggests that the water is considered unfit for irrigation, alkali hazards could be responsible for its unsuitability [38]. KR has value ranging from 0.01 to 0.77 with an average value of 0.36 see Table 5 . From value obtained from KR, it is considered fit for agricultural use (irrigation). 
From eqn. 8 applied the value of TH ranges from 72.00 - 425.50 with an average value of 189.12 as shown in Table 4 and 5 Sample location LBT/11 and 14 falls within the soft water category and classified good for irrigation, while sample location LBT/5, 7, 8, 12 and 13 is classified as moderately hard, sample location LBT/1, 2, 3, 6, 9 and 10 is within the hard category and lastly sample location LBT/04 falls within the very hard category see Figure 8. This implies that the sampled location is unsuitable for irrigation.

Table 4: Classification of Water Based on Total Hardness [48]

\begin{tabular}{|c|c|c|}
\hline $\begin{array}{l}\text { Total } \\
\mathrm{CaCO}_{3}(\mathrm{mg} / \mathrm{L})\end{array}$ & Water Class & Number of Samples \\
\hline$<75$ & Soft & LBT $/ 11$ and 14 \\
\hline $\begin{array}{l}75-150 \\
150-300\end{array}$ & $\begin{array}{l}\text { Moderately Hard } \\
\text { Hard }\end{array}$ & $\begin{array}{l}\text { LBT } / 5,7,8,12 \text { and } 13 \\
\text { LBT } / 1,2,3,6,9 \text { and } 10\end{array}$ \\
\hline$>300$ & Very Hard & LBT $/ 4$ \\
\hline
\end{tabular}

\subsubsection{Potential Salinity}

Potential salinity is classified as stated below; excellent to good, value below $5(<5)$, good to injurious value between 5 to $10(5-10$, injurious to unsatisfactory value above $10(>10)$. From detailed interpretation it was observed that, all of the samples fall in excellent to good. With value ranging from 0.00 to 0.47 with an average value of 0.10 see Table 5. From value obtained from PS, on could conclude that the values are considered suitable for irrigation.

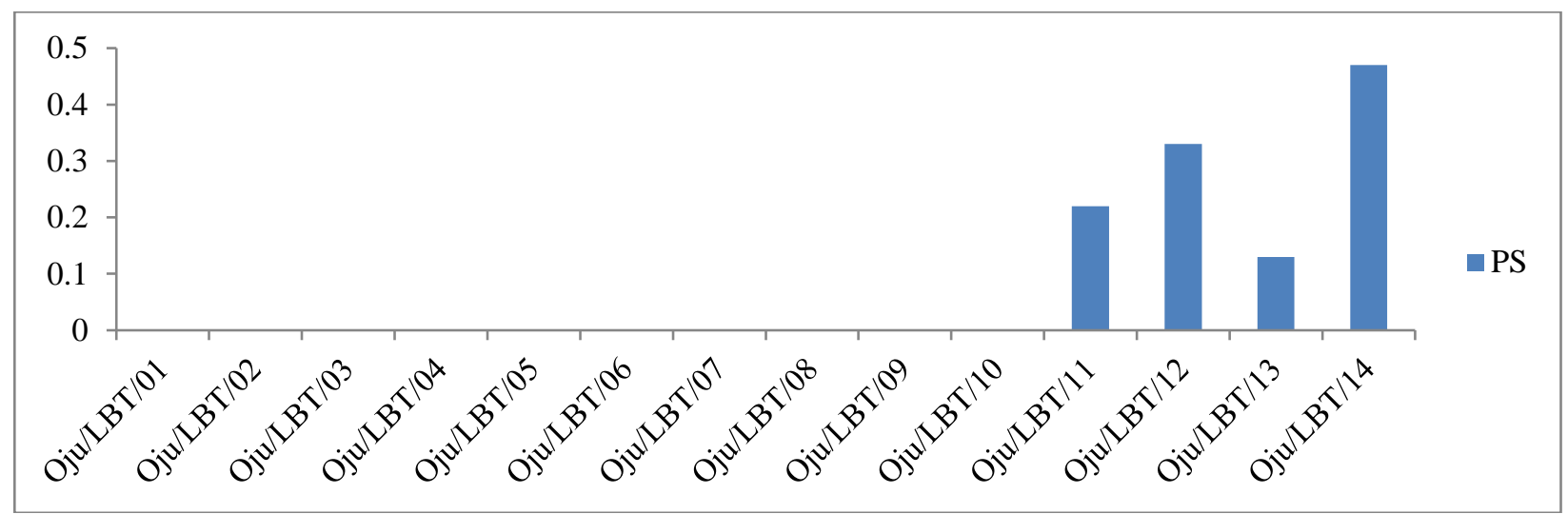

Figure 6: Barchart showing plot of PS against Sample Location

Table 5: Result of Irrigation parameters

\begin{tabular}{lllllllll}
\multicolumn{2}{l}{ Table 5: Result of rrigation parameters } \\
\hline Sample code & EC & TH & MAR & KR & Na\% & SSP & SAR & PS \\
\hline LBT/01 & 727 & 252.5 & 32.47 & 0.23 & 23.3 & 18.94 & 0.74 & 0.00 \\
LBT/02 & 531 & 213.5 & 25.02 & 0.34 & 38.8 & 27.57 & 1.13 & 0.00 \\
LBT/03 & 590 & 225 & 0.00 & 0.01 & 1.55 & 1.53 & 0.04 & 0.00 \\
LBT/04 & 760 & 425.5 & 61.98 & 0.22 & 22.20 & 18.17 & 0.94 & 0.00 \\
LBT/05 & 670 & 146.00 & 0.00 & 0.38 & 38.69 & 27.90 & 0.94 & 0.00 \\
LBT/06 & 318 & 203.00 & 35.7 & 0.11 & 11.82 & 10.54 & 0.33 & 0.00 \\
LBT/07 & 430 & 139.50 & 24.63 & 0.34 & 34.7 & 25.60 & 1.38 & 0.00 \\
LBT/08 & 404 & 144.00 & 6.84 & 0.211 & 21.18 & 17.47 & 0.50 & 0.00 \\
LBT/09 & 314 & 205 & 53.9 & 0.56 & 56.82 & 36.2 & 0.29 & 0.00 \\
LBT/10 & 362 & 241 & 39.21 & 0.09 & 9.33 & 8.53 & 0.29 & 0.00 \\
LBT/11 & 253 & 72 & 6.94 & 0.68 & 68.75 & 4.07 & 0.72 & 0.22 \\
LBT/12 & 146 & 80 & 6.50 & 0.46 & 46.87 & 38.65 & 0.8 & 0.33 \\
LBT/13 & 254 & 108.5 & 0.00 & 0.77 & 77.80 & 43.78 & 1.08 & 0.13 \\
LBT/14 & 127 & 73 & 0.00 & 0.60 & 60.2 & 37.60 & 0.73 & 0.47 \\
\hline Minimum & $\mathbf{1 2 7}$ & $\mathbf{7 2}$ & $\mathbf{0 . 0 0}$ & $\mathbf{0 . 0 1}$ & $\mathbf{1 . 5 5}$ & $\mathbf{1 . 5 3}$ & $\mathbf{0 . 0 4}$ & $\mathbf{0 . 0 0}$ \\
Maximum & $\mathbf{7 6 0}$ & $\mathbf{4 2 5 . 5}$ & $\mathbf{6 1 . 9 8}$ & $\mathbf{0 . 7 7}$ & $\mathbf{7 7 . 8}$ & $\mathbf{4 3 . 7 8}$ & $\mathbf{1 . 3 8}$ & $\mathbf{0 . 4 7}$ \\
Average & $\mathbf{4 2 3 . 3 1}$ & $\mathbf{1 8 9 . 1 2}$ & $\mathbf{2 2 . 1 9}$ & $\mathbf{0 . 3 6}$ & $\mathbf{3 6 . 9 6}$ & $\mathbf{2 2 . 6 1}$ & $\mathbf{0 . 7 0}$ & $\mathbf{0 . 1 0}$ \\
\hline
\end{tabular}

6.1.7 Electrical Conductivity $(E c)$

Sawid and Issa 47, stated that electrical conductivity is considered as important criteria in measuring of salinity hazard to crops as it reflects the TDS in groundwater. Ec value within the study area ranges from 127 to $760 \mu \mathrm{S} / \mathrm{cm}$ with an average value 423.31 falls within excellent and good category see Table 6 . The value range of EC shows that groundwater is considered suitable for irrigation purpose.

Table 6: Grading of Groundwater Based on EC

\begin{tabular}{ccc}
\hline Salinity Hazard (Class) & EC $\mu / \mathrm{Scm}$ & Sampling Points \\
\hline Excellent(C1) & $<250$ & LBT $/ 12$ and 14 \\
Good (C2) & $250-750$ & LBT $/ 01,02,03,04,05,06$, \\
& & $07,08,08,09,10,11,13$ \\
Doubtful(C3) & $750-2250$ & \\
Unsuitable(C4) & $>2,250$ & \\
\hline
\end{tabular}

\subsection{Hydrogeochemical Facies Analysis}

\subsection{Groundwater evaluation of the study area using Gibbs Plot}

Charactertics of anions and cations in groundwater display certain physicochemical attribute that result from groundwater's interaction with rock and soil, in process of flowing through water bearing unit [49]. Aquifer show properties of water bodies with various chemical compositions [50]. Such properties can be linked to hydrogeochemical facies/geogenic. In most case hydrogeochemical facies are usually influence by the aquifer (rock that serves as water bearing unit) and groundwater flow. The distribution of anions $\left(\mathrm{Cl}^{-}, \mathrm{HCO}^{-}\right)$and cations $(\mathrm{Na}+, \mathrm{Ca} 2+)$ as well as the TDS were used to plot the Gibbs diagram 
in other to show the major process that has influence on groundwater within the study area such as; rock dominance, evaporation dominance, precipitation dominance. Gibbs diagram helps in interpreting the influence of hydrogeochemical processes such as; precipitation, rock-water interaction mechanism and evaporation on groundwater chemistry. The interaction between groundwater and aquifer minerals has greater influence groundwater quality which is useful in predicating the source of groundwater as shown in Figure 6. Previous research within the ASG of the LBT, has shown that rock dominance is the process controlling groundwater chemistry [3,50]. From this study it was observed that rock dominance is the major factor that influence groundwater except for sample location LBT/13, while for anions it was observed that rock dominance is the major factor that influence groundwater except for sample location LBT/11, 12 and 14 see Figure 7.
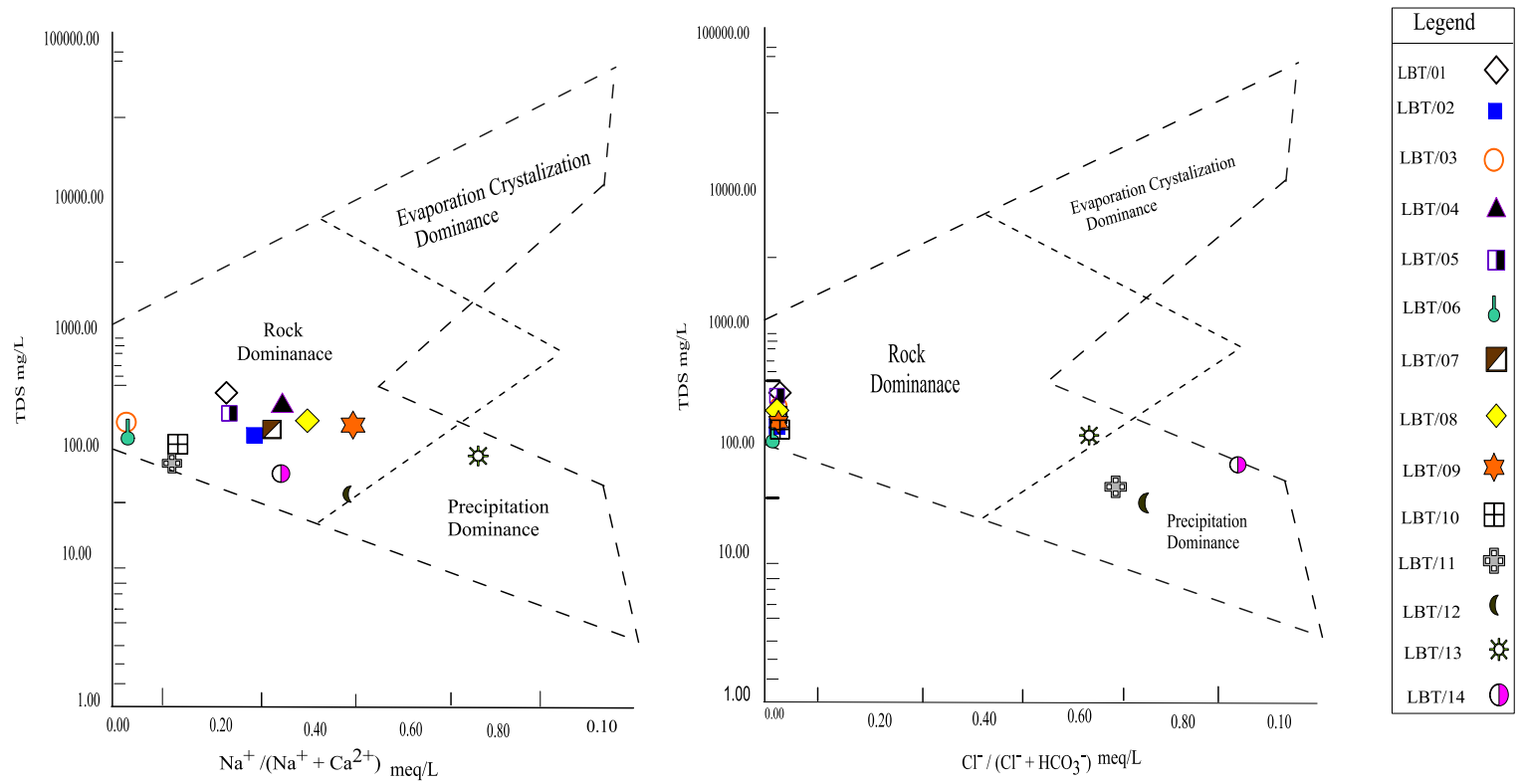

Figure 7: Gibb's Plot of Water Sampled Location of the Study Area

\subsection{Chadba Plots}

Geochemical classification and hydrochemical parameters of groundwater see Figure 8 [52]. One (1). Alkaline earths above alkali metals; 2. alkali metals above alkaline earths; 3 . weak acidic anions above strong acidic anions; 4 . strong acidic anions exceed weak acidic anions; 5 . Ca2+- Mg2+-HCO3-water

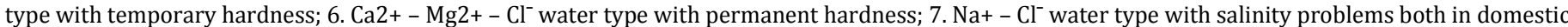
and other use. 8. $\mathrm{Na}+-\mathrm{HCO3}^{-}$water type causes foaming problems in domestic use. From Figure 8. Sample locations LBT/01, 02, 05, 07, 08,09 and 10 falls within $\mathrm{Ca} 2+-\mathrm{Mg} 2+-\mathrm{HCO3}^{-}$water type that implies that the listed sample location can be classified as temporary hard water. While sample location

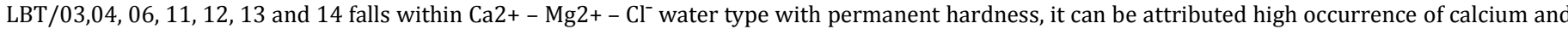
magnesium in sampled water see Fig. 8. Previous research by Eyankware 4 stated that groundwater within the Asu River Group falls within Ca2+ - Mg2+ $\mathrm{Cl}^{-}$permanent hard category.

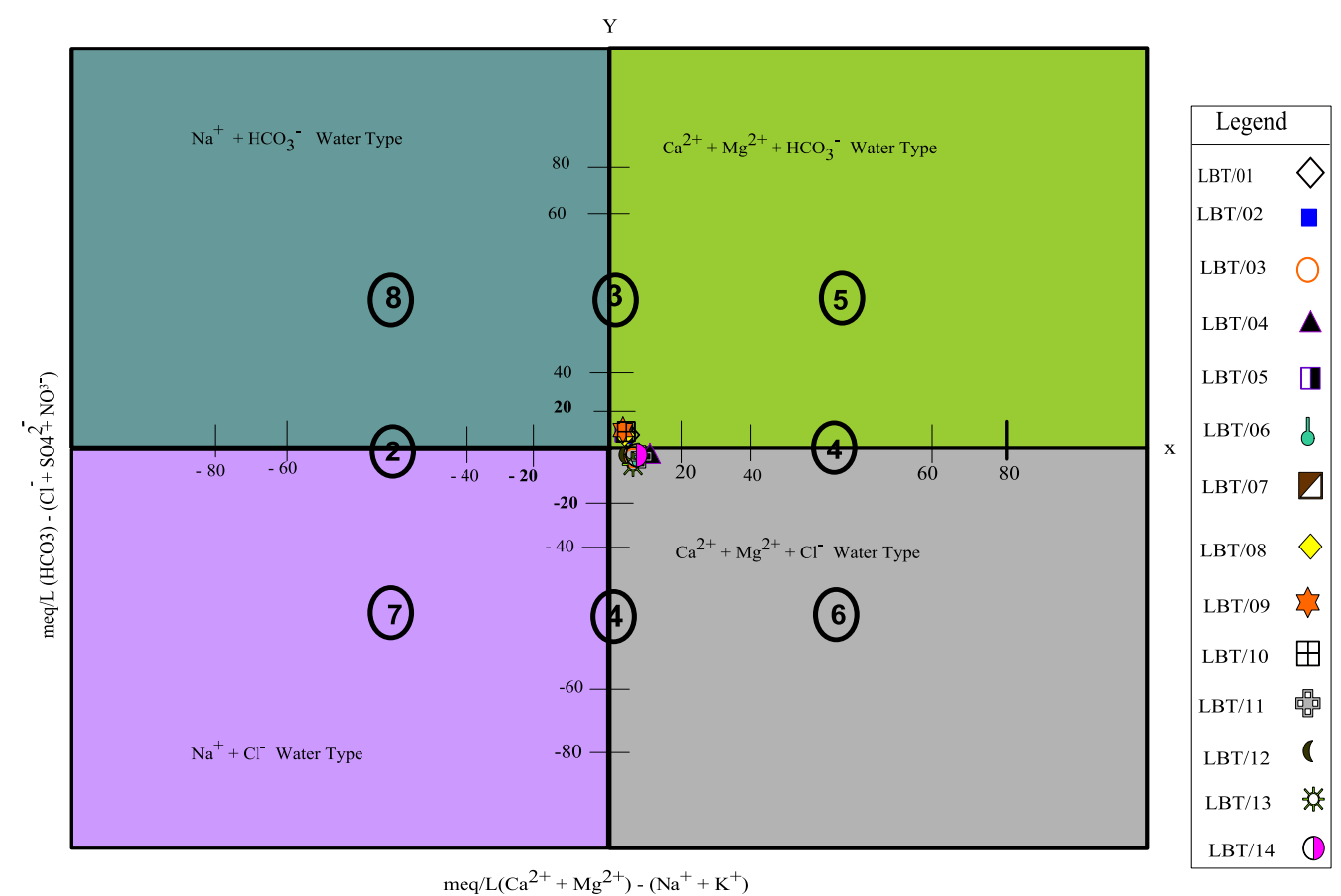

Figure 8: Chadba's Diagram showing Groundwater type of the Study Area

\subsection{Ion Exchange}

Factor controlling groundwater chemistry was also evaluated using bivariate diagrams such as $\mathrm{Cl}^{-}$versus $\mathrm{Na}+\mathrm{Mg} 2+$ versus $\mathrm{Ca} 2+, \mathrm{SO}^{-}{ }^{-}$versus $\mathrm{Ca} 2+$ and $\mathrm{Ca} 2++\mathrm{Mg} 2+$ versus $\mathrm{Ca} 2+$ as widely used see (Figure 9a to 9d) respectively [49-51]. As for the plot of $\mathrm{Cl}^{-}$against Na+ mineral weathering was observed to have occurred, but ion exchange is dominant process governing groundwater chemistry. Silicate weathering and ion exchange was observed to be major process controlling groundwater chemistry from $\mathrm{Na}+$ against $\mathrm{Cl}^{-}$see Figure 9a. From Figure 9b plot of Mg2+ versus Ca2+ showed both sides of 1:1 line, this implies that dissolution, ion exchange, mineral weathering and evaporation as the main factor governing groundwater chemistry. While from Figure $9 \mathrm{c}$ plot of S042- versus $\mathrm{Ca} 2+$, the occurrence of dissolved gypsum in the groundwater could be caused from the application of gypsum for the improvement of the 
soil in the present study area. Figure 9d Ca2+ + Mg2 + versus Ca2+ it was observed that large percentage of groundwater falls within reverse ion exchange.

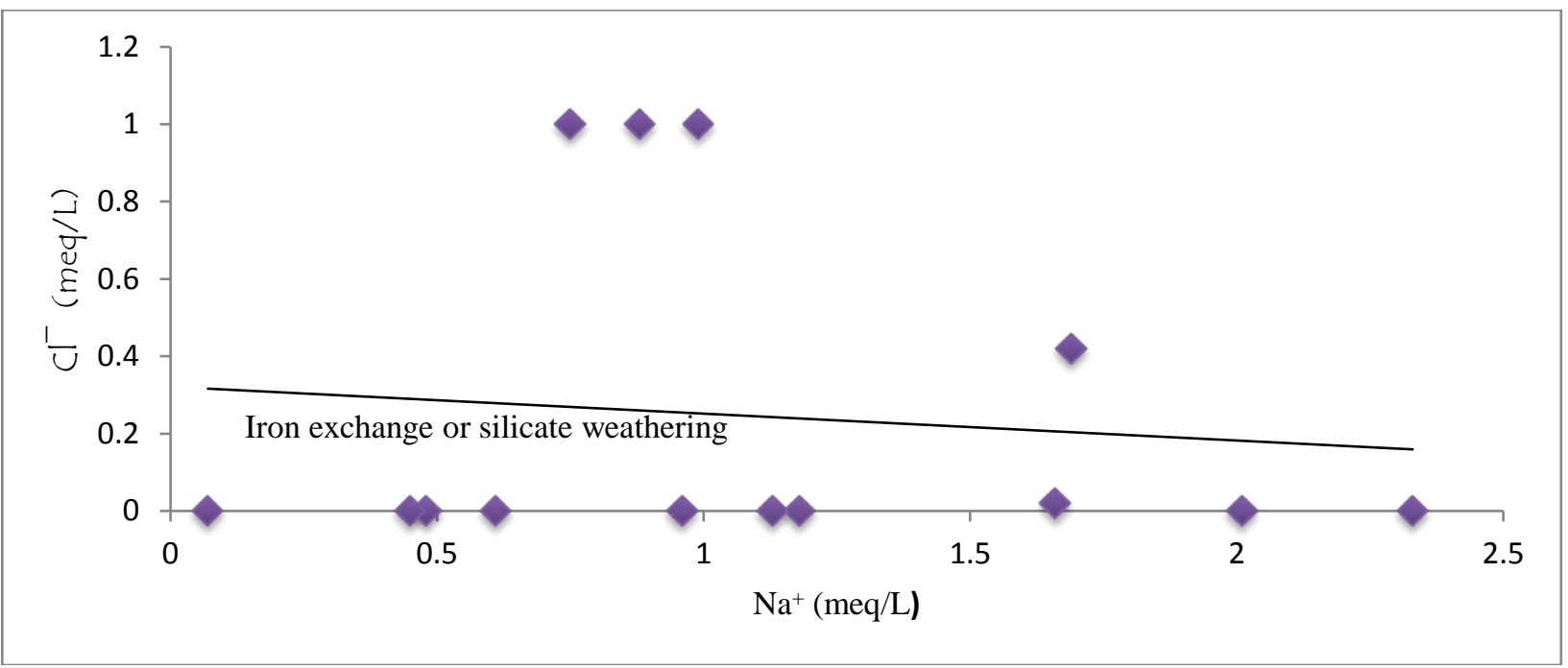

Figure 9a: Correlation between $\mathrm{Cl}^{-} / \mathrm{Na}^{+}$.

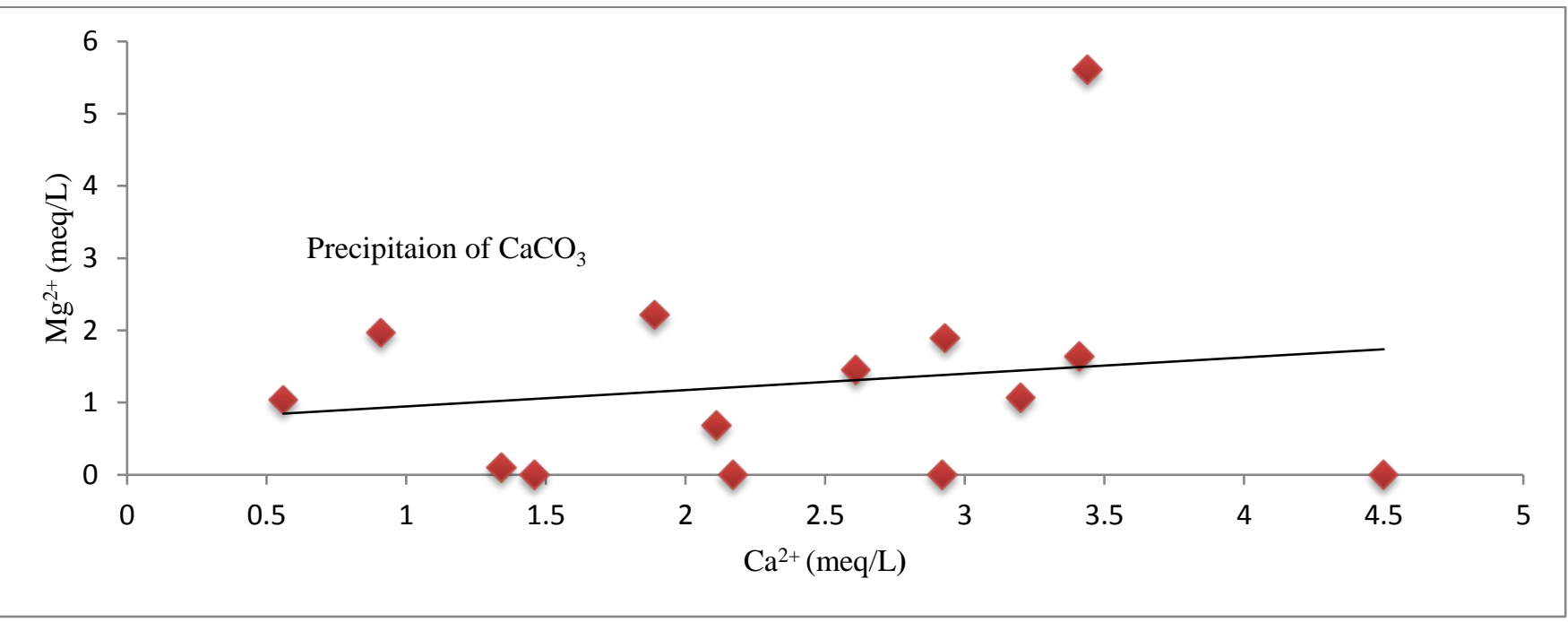

Figure 9b: Correlation between $\mathrm{Mg}^{2+} / \mathrm{Ca}^{2+}$.

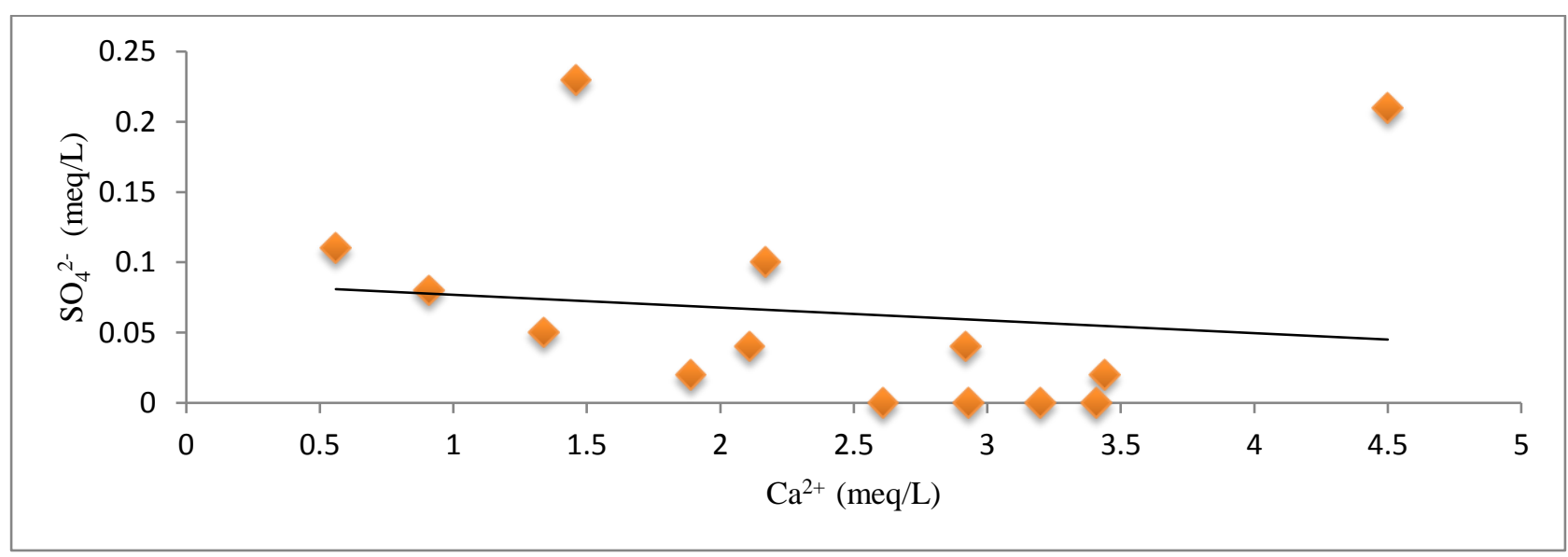

Figure 9c: Correlation between $\mathrm{SO}^{2-} / \mathrm{Ca}^{2+}$. 


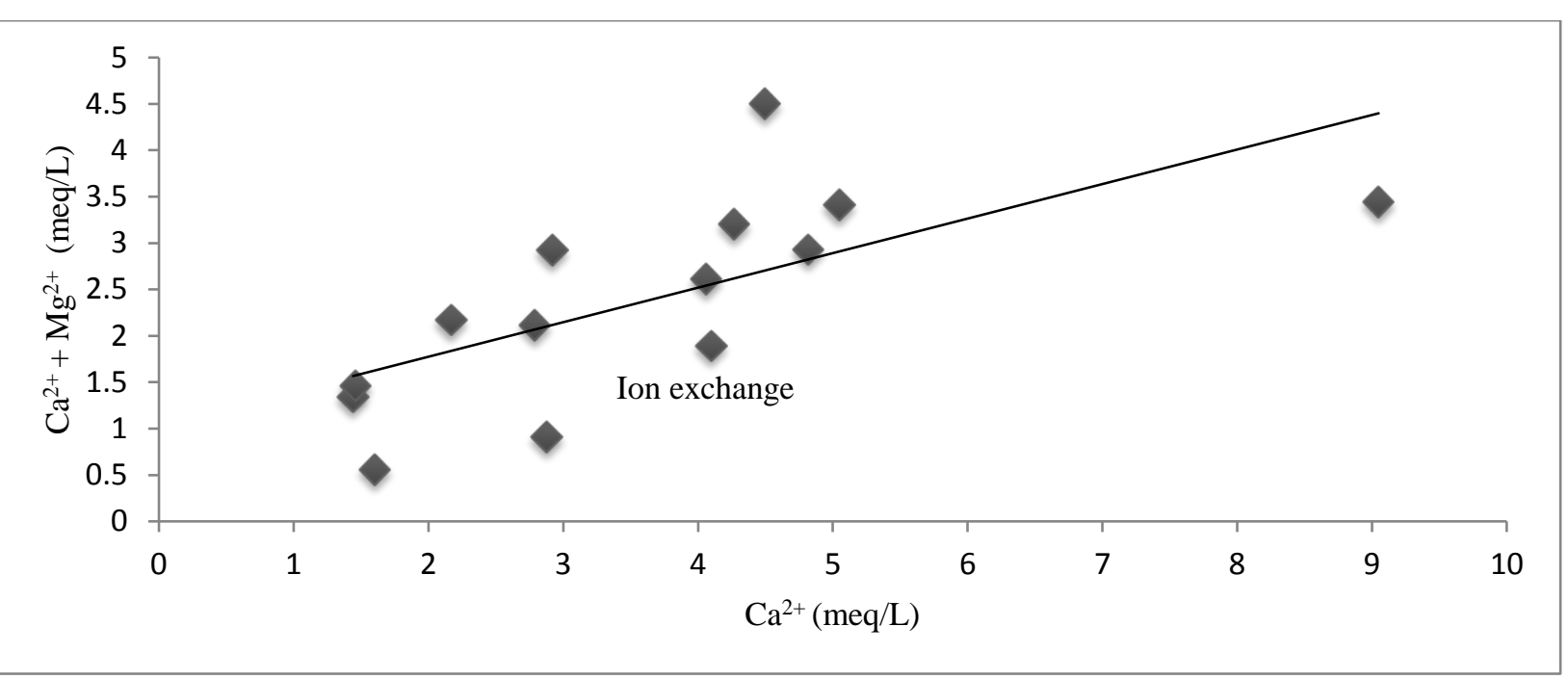

Figure 9d: Correlation between $\mathrm{Ca}^{2+}+\mathrm{Mg}^{2+} / \mathrm{Ca}^{2+}$

\section{4. $\mathrm{pH}$}

[53], stated that p provide detail information regarding types of geochemical equilibrium. The $\mathrm{pH}$ of the analyzed samples varies from 6.5 to 7.7 with a mean value of 6.88 as shown in Table 3 in the study area, $\mathrm{pH}$ ranges between 6.0 to 7.0 is considered suitable for irrigation [54]. Sample locations are considered suitable for irrigation except for LBT/05, 06 and 13 which are considered unsuitable for irrigation.

\subsection{Conclusion}

This research was aim at evaluating the process governing groundwater quality and its suitability for irrigation;

\subsection{Irrigation Parameters}

From the findings it was observed that SSP 1.53 to 43.78 with an average value of 22.6, value below 50 is considered suitable for irrigation. Based on this value obtained from SSP is considered suitable for irrigation. Result obtained from MAR were considered suitable for irrigation except LBT/04 with value of 61.98 , hence his LBT $/ 04$ is considered not fit for irrigation. Na\% is very paramount when discussing groundwater suitability for irrigation, from findings $\mathrm{Na} \%$ is considered fit for irrigation. As for SAR sampled locations LBT/12 and 14 falls within the C1 (excellent) category, while LBT/02, 03, 05, 06, 07, 08, 09, 10 and 11 falls within the C2 (good) category and LBT/01 and 04 falls within the C3 (doubtful). SAR plotted against electrical conductivity (dS/m) showed that groundwater samples falls within slightly to moderate reduction infiltration category. From findings groundwater do not have influence on the soil infiltration attribute. Based on the value range of KR, it is considered fit for irrigation. Hardness of water is considered important in determining suitability of water for various use. The value of TH ranges from 72.00 to 425.50 with an average value of 189.12 . Sample location LBT/11 and 14 , while sample location LBT/5, 7, 8, 12 and 13 is classified as soft, moderately hard respectively. Sample location LBT/1, 2, 3, 6, 9 and 10 and lastly sample location LBT/04 falls within hard to very hard category respectively. This implies that the sampled location is unsuitable for irrigation. PS has value ranging from 0.00 to 0.47 with an average value of 0.10 , hence is considered suitable for irrigation. Ec value ranges falls within excellent to good category, based on this the sample location are considered suitable for irrigation. $98 \%$ of groundwater is considered suitable for irrigation based on $\mathrm{pH}$ result.

\subsection{Gibbs Plot}

Gibbs Plot, it was observed that rock dominance is the major factor controlling groundwater chemistry within except for LBT/11, 12 and 14 where precipitation dominance has influence on groundwater.

\subsection{Chadba Plot}

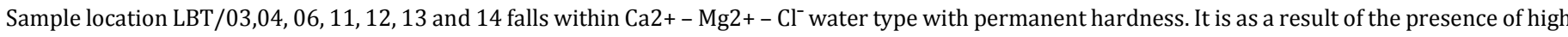
concentration of $\mathrm{Ca} 2+$ and $\mathrm{Mg} 2+$ in water sample. While sample locations LBT/01, 02, 05, 07, 08, 09 and 10 falls within Ca2+- Mg2+- $\mathrm{HCO3}^{-}$water type that implies that the listed sample location can be classified as temporary hard water this could be attributed presence of high concentration of magnesium and calcium.

\subsection{Ion exchange}

From findings it was observed that weathering is the major processing influence groundwater in the study area.

\section{References}

[1] I.A. Goni, P. Edet, S. Olasehinde, P. Adelana, and Vrbka, "An overview of the geology and hydrogeology of Nigeria, IAH - Selected Papers on Hydrogeology", 2008.

[2] M.O. Eyankware, P.N. Obasi, and O.C. Akakuru, "Use of Hydrochemical Approach in Evaluation of Water Quality around the Vicinity of Mkpuma Ekwaoku Mining District, Ebonyi State, SE. Nigeria for Irrigation Purpose”, Indian Journal of Science, vol. 23(88), pp, 881-895, 2016.

[3] M.O. Eyankware, "Hydrochemical Apprasial of Groundwater for Irrigation Purpose: A Case Study of Ekaeru Inyimagu and Its Adjoining Area, Ebonyi State, Nigeria," Indian Journal of Science, Vol. 23(88), pp. 924-94, 2016.

[4] M.O. Eyankware, "Hydrogeochemical Evaluation of Groundwater for Irrigation Purposes in Mining Areas of Umuoghara Near, Abakaliki, SE. Nigeria," Science and Technology, Vol. 3(9), pp. 1-19, 2017.

[5] M.O. Eyankware, V.S. Nnajieze, and C.G. Aleke, "Geochemical Assessment of Water Quality for Irrigation Purpose, in Abandoned Limestone Quarry pit at Nkalagu area, Southern Benue Trough Nigeria," Environ Earth Science, Vol. 77, pp. 66, 2018a. https://doi.org/10.1007/s12665-018-7232-x.

[6] V.O. Ezeh, M.O. Eyankware, O.O. Irabor, and P.N. Nnabo, "Hydrochemical Evaluation of Water Resources in Umuoghara and its environs, near Abakaliki, South Eastern Nigeria," International Journal of Science and Healthcare Research, Vol. 1(2), pp. 23-31, 2016

[7] M.J. Islam, M.A. Hakim, M.M. Hanafi, S.J. Abdul, A. Sharmin, S. Aysha, A.K.M., Shajedur, M.A. Islam, and M.A. Halim, "Hydrogeochemical quality and suitability studies of groundwater in northern Bangladesh," Journal of Environmental Biology, Vol. 35, pp. 765 -779, 2013. 
[8] A. Sreenivasa, and N.A. Ajaykumar, "Water Quality Assessment for Drinking and Irrigational Suitability of Galgibagh River Sub-basin (GRSB), Goa," International Journal of Scientific Research in Science, Engineering and Technology, Vol. 1(6), pp. 327-331, 2015.

[9] C.K. Jain, A. Bandyopadhyay, and A. Bhadra, "Assessment of Ground Water Quality for Irrigation Purpose, District Nainital, Uttarakhand, India", Journal of Indian Water Resources Society, Vol. 32(3-4), pp. 8-14, 2012.

[10] P.N. Obasi, M.O. Eyankware, B.B.E. Akudinobi, and M.O. Nweke, "Hydrochemical Investigation of Water Resources around Mkpuma Ekwaoku Mining District, Ebonyi State Southeastern Nigeria," African Journal of GeoScience Research, Vol. 3(3), pp. 01-07, 2015.

[11] Y.O. Balogun, “Senior Secondary school Atlas," 2nd Edition Longman, Pp. 161, 2005.

[12] M.D. Cocker, "Geochemistry and hydrochemistry of the Oconee River Basin. In: Hatcher KJ (ed) Proceedings of 1995," Georgia water resources conference held on the 11-12 April, University of Georgia, pp. 67-70, 1995

[13] K. Pazand, Y. Gbanbari, B. Aghavali, and A. Hezarkhani, "Groundwater Geochemistry in the middle Meshkinshahr basin of Ardabil province in Iran," Environ Earth Sci., pp. 1131-8, 2011.

[14] S.O. Nwachukwu, "The Tectonic Evolution of the Southern Portion of the Benue Trough, Nigeria," Geological Magazine, Vol. 109 (05), pp. 411-419, 1972.

[15] C.R. Cratchley, and G.P. Jones, "An Interpretation of the Geology and Gravity Anomalities of Benue valley," Nigeria: Oversea Geological survey Geophysics, Vol. 1, pp. 29, 1965.

[16] K. Burke, T.F.G. Dessavaige, and A.J. Whiteman, “The Opening of Gulf of Guinea and Geological History of the Benue Depression and Niger Delta," Nature Physics. Sci., Vol. 233, pp. 51-55, 1971.

[17] N.K. Grant, “South Atlantic, Benue Trough and Gulf of Guinea Cretaceous Triple Junction,” Bull. Geo. Soc. Am., Vol. 82, pp. 2295-2298, 1971.

[18] J. Benkhelil, "The Origin and Evolution of the Cretaceous Benue Trough Nigeria." Journal of African Earth Sciences (and the Middle East), Vol. 8(2\&4), pp. 251-282, 1989

[19] S.C. Obiora, and A.C. Umeji, “Petrographic Evidence for Regional Burial Metamorphism of the Sedimentary Rocks in the Lower Benue Rift," J. African Journal of Earth Science, Vol. 38 (3), Pp 269, 2004.

[20] A. Simpson, "The Nigerian Coalfield. The geology of parts of Onitsha, Owerri and Benue Provinces," Bulletin Geological Survey Nigeria, Vol. 24(8), pp. $85,1954$.

[21] R.A. Reyment, "Aspects of the Geology of Nigeria: The Stratigraphy of the Cretaceous and Cenozoic Deposits," Ibadan University, 1965.

[22] C.S. Nwajide, “Geology of Nigeria’s Sedimentary Basin,” CSS Bookshops Ltd Lagos, Pp. 565, 2013.

[23] C.A. Kogbe, "Geology of Nigeria," Elizabethan Publishing Company, 1976.

[24] A.D.N. Bain, “The Nigerian coalfields section 1. Enugu area," Bull. Geol. Surv. Nig, Vol. 6, pp. 106-120, 1924.

[25] M.E. Offodile, “The Geology of the Middle Benue, Nigeria,” Paleontologiska inst., Uppsala universitet, 1976.

[26] S.O. Nwachukwu, "The Tectonic Evolution of the southern portion of the Benue Trough, Nigeria," Geological Magazine, Vol. 109(05), pp. 411-419, 1972.

[27] L.C. Amajor, "The Cenomanian Hiatus in the Southern Benue Trough, Nigeria," Geological Magazine, Vol. 122(01), pp. 39-50, 1985.

[28] C.S. Nwajide, "Cretaceous Sedimentation and Paleogeography of the Central Benue Trough," In: Ofoegbu, C.0; (Ed.), The Benue Trough structure and Evolution International Monograph Series, Braunschweig, pp. 19-38, 1990.

[29] APHA, "Standard methods for the examination of water and wastewater, 22nd Edn," American Public Health Association, 2012.

[30] W. Hounslaw, “Water Quality Data: Analysis and Interpretation,” CRC Press, Boca Raton, Pp. 71-127, 1995.

[31] P.A. Domenico, and F.W. Schwartz, “Physical and Chemical hydrology,” John Wiley and sons, New York, 410, 1990.

[33] L.A. Richards, "Diagnosis and improvement of saline and alkali soils. In: United States Salinity Laboratory Staff Agricultural Handbook No. 60," The United States Government Printing Office, Washington DC, 1969.

[34] D.K. Todd, “Groundwater Hydrology," 2nd ed. John Wiley and Sons, Inc. New York, pp. 516, 1980.

[35] H.M. Raghunath, “Groundwater,” 2nd Ed. Wiley Eastern Ltd. New Delhi, India, pp. 344-369, 1987.

[36] F.M. Eaton, "Significance of carbonates in irrigation waters," Soil Sci. Vol. 39, pp. 123-133, 1950

[37] L.D. Doneen, “Water quality for agriculture," Department of irrigation, University of California. Davis. Pp. 48, 1964.

[38] W.P. Kelly, “Use of Saline Irrigation Water,” Soil Sci, Vol. 95(4), pp. 355-39, 1963

[39] L.D. Doneen, "Stalinization of soil by salt in the irrigation water Amer," Geophys. Union. Trans., Vol. 35, pp. 943-950, 1954.

[40] R.J. Gibbs, “Mechanisms controlling world water chemistry,” Science, Vol. 170(3962), 1088-1090, 1970.

[41] D.M. Joshi, A. Kumar, and N. Agrawal, “Assessment of irrigation water quality of River Ganga in Haridwar District India," J. chem.., Vol. 2(2), 285-292, 2009. 
[42] F.F. Munshower, "Practical Handbook of Disturbed Land Re-vegetation,” Lewis Publishers, Boca Raton, Florida, 1994.

[43] L.V. Wilcox, “Classification and use of irrigation water,” USDA, Circular, Washington, DC, USA, pp. 969, 1955.

[44] A.O. Talabi, O.L. Afolagboye, M.N. Tijani, J.A. Aladejana, and Ogund, "Hydrogeochemistry of Some Selected Springs' Waters in Ekiti Basement Complex Area, Southwestern Nigeria," International Journal of Engineering and Science, Vol. 3(2), pp. 19-30, 2014.

[45] U.S. Salinity Lab, "Saline and Alkali Soils - Diagnosis and Improvement of U.S. Salinity Laboratory," Agriculture Hand Book No.60, Washington, 1954.

[46] B. Hanson, S.R. Grattan, and A. Fulton, “Agricultural Salinity and Drainage. University of California Irrigation Program,” Davis: University of California, 1999.

[47] F.A. Sawid, and A.A. Issa, "Assessment of groundwater quality for drinking and irrigation purposes," Martubah plain, eastern Libya Transactions on Ecology and The Environment, Vol. 196, pp. $311-325,2015$.

[48] C.N. Sawyer, and P.L. McCarty, “Chemistry for sanitary engineer,” 2nd Ed., McGraw-Hill, New York, Pp. 518, 1967.

[49] R.N. Subba, and R.P. Surya, "Major ion chemistry of Groundwater in a River Basin: a study from India," Environ Earth Sci., Vol. 61, pp. 757-775, 2010.

[50] M.O. Eyankware, C. Ogwah, and G.C. Okeke, "Geochemical Evaluation of Groundwater Origin Using Source Rock Deduction and Hydrochemical Facies at Umuoghara Mining Area, Lower Benue Trough, SE Nigeria," International Research Journal of Earth Science, Vol. 6(10), pp. 1-11, 2018b.

[51] 0.0. Omo-Irabor, M.O. Eyankware, and C. Ogwah, "Integration of Hydrogeochemical Analytical Methods and Irrigation Parameters in the Evaluation of Groundwater Quality at Ibinta, Southern Benue Trough Nigeria," FUPRE Journal of Scientific and Industrial Research, Vol. 2 (1), pp. 38-49, 2018c.

[52] D.K. Chadha, "A proposed new diagram for geochemical classification of natural waters and interpretation of chemical data," Hydrogeol. J., Vol. 7, pp. 431-439, 1999.

[53] J.D. Hem, "Study and interpretation of the chemical characteristics of natural water," 2nd edn. US Geol Surv Water Supply Paper, Vol. 2254, pp. 363, 1985.

[54] www.spectrumanalytic.com. 